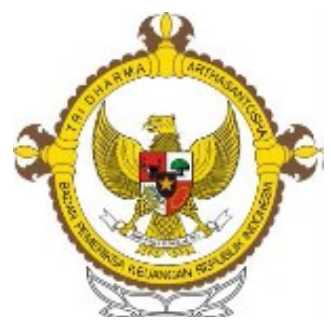

JURNAL

TATA KELOLA \& AKUNTABILITAS KEUANGAN NEGARA

Volume 5, Number 1, Jan-Jun 2019, 73-89

e-ISSN 2549-452X

p-ISSN 2460-3937

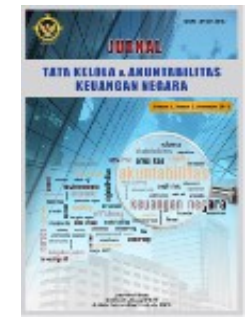

\title{
ANALYSIS OF THE RESPONSIBILITY OF GOVERNMENT INSTITUTIONS IN RETURNING STATE LOSSES ACCORDING TO LAW NUMBER 30 OF 2014 ON GOVERNMENT ADMINISTRATION
}

\author{
Joseph Harry Krisnamurti ${ }^{1}$ and Belinda Gunawan ${ }^{2}$ \\ Badan Pemeriksa Keuangan Republik Indonesia ${ }^{1}$ \\ Faculty of Law, University of Indonesia ${ }^{2}$ \\ joseph.krisnamurti@bpk.go.id ${ }^{1}$ \\ belinda.gunawan61@ui.ac.id ${ }^{2}$
}

\begin{abstract}
The passage Law Number 30 of 2014 on Government Administration has raised its own problems due to its clauses regarding legal subjects that could be charged with reinstating state losses. This is due to the fact that such Law provides that government institutions can be determined as the party that is responsible for reinstating state loss that have occurred, which contradicts with the definition of state loss as stipulated in the applicable state finance laws that position the state as the party suffering the loss when a state loss is incurred. This study has been conducted using a normative legal research method which aims to test consistency between the legal norms applied in Law Number 30 of 2014 and the laws on state finance. Result of this study demonstrates that government institutions cannot be designated as the legal subject responsible for state losses. Such stipulation is not legally logical as it asserts that government institutions that are in fact representatives of the state may be required to return or pay the state losses to the state. Therefore there needs to be a revision to the relevant provisions of Law Number 30 of 2014 in order for such law to be in line with the provisions that presently govern state finance.
\end{abstract}

KEYWORDS:

Responsibility; government officials; state losses; Law Number 30 of 2014 


\section{INTRODUCTION}

Indonesia's definition of state finances can be found in Law Number 17 of 2003, which is "all the rights and obligations of the state that can be assigned monetary value, and any item in the form of money or goods that can be acquired to become the property of the state with respect to the exercise of such rights and obligations." This definition closely follows the definition of state finances as stipulated by Van der Kemp, namely all rights that can be assigned with monetary value, and all items (whether in the form of money or goods) that can become the property of the state with respect to such rights (Tjandra, 2014). In order to determine whether or not a loss has been suffered by the State, most countries of the world have an independent state institution having supervisory, reporting and audit authority (Lary \& Taylor, 2012). Indonesia delegates such mandate to The Audit Board of Republic of Indonesia (Badan Pemeriksa Keuangan - BPK) based on Article 23E of The Amended Constitution of The Republic of Indonesia 1945.

The concept of state finances in Indonesia is closely related to the concepts of state losses and compensation from a legal perspective. Makawimbang (2014) defines state financial loss as the following:

1. The loss or diminishment of the State's rights and obligations that can be attributed with monitory value, as a consequence of a willful unlawful act in the form of:

a. the right of the State to collect taxes, issue and circulate money, and provide loans;

b. the State's obligation to deliver governmental public services and pay third taxes;

c. State revenue and spending;

d. Regional government revenue and spending; and e. State/regional government assets that are self-managed or managed by other parties in the form of money, commercial papers, receivables, assets, and other rights that can attributed with monetary value, including separated assets of central/regional government-owned enterprises.

2. The loss or diminishment of any item in the form of money or goods that can become the property of the State with respect to the exercise of its rights and obligations as a consequence of the willful conduct of an unlawful act in the form of:

a. assets of other persons controlled by the government in the exercise of governmental functions and/or for public interest; and

b. assets of other persons acquired using facilities provided by the government.

According to the theory put forward by law experts, Simatupang (2011) concluded that the elements of state loss are:

1. Loss is strictly a diminishment of money, goods, and commercial papers;

2. Definite. The diminished money, goods, and commercial papers have been determined of its value in a financial report;

3. Real. The diminished money, goods, and commercial papers have become the rights or obligations of the State; and

4. The consequence of an unlawful action (criminal/civil) or negligence.

The purpose of compensation is to allow the aggrieved party, as the victim, to receive recovery or compensation from the party causing the loss as a result of the conduct of an unlawful act (Herstein, 2015). Article 1 paragraph 16 of Law Number 15 of 2006 stipulates that:

"Compensation is an amount of money or goods that can be attributed with monetary value that must be returned to 
the state/regional government by an individual or entity that has committed an unlawful act, whether willfully or in negligence."

Bentham (2010) gives the definition of compensation as something given to the aggrieved party of an equitable value by taking into account any damage caused, and such compensation will be deemed as duly settled if the goodwill imparted is comparable to the damage suffered. With respect to damaged or destroyed goods, compensation to be given for future adverse situations are similar goods or goods of equal value to the suffering party, while compensation for past sufferings should be for any shortfall that is experienced (Bentham, 2010). This understanding is in line with the views of Agustina, Nieuwenhuis, Hijma, and Suharnoko (2012), who stipulate that with respect to financial loss (vermogenschade), compensation is usually comprised of reparation for loss suffered and profit expected to be received (gederfdewinst), although to determine the amount of such compensation is not as simple as one might expect. Compensation for anticipated profits can be equated to compensation for past suffering as defined by Bentham (2010). This is also similar to the concept of compensation from an economic perspective that recognizes compensation in the form of opportunity cost or imputed cost, such interest that are not actually accrued but must be taken into account in calculating compensation (Tuanakotta, 2007).

Soepardi (2006) states that there are three issues that must be examined as a possible cause for state financial loss, namely the conduct of treasurers, the conduct of nontreasurer civil servants, and the conduct of third parties. State loss is an occurrence that must be accounted for. In this regard, legal entities or persons that can be held accountable for the occurrence of a State loss are treasurers as functional officers, civil servants as government officials, and third parties such as contractors or goods and service providers, arising from an unlawful act, whether committed willfully or in negligence.

Law on compensation would overlap with regulations on government administration, given that the management of and accountability for state finances is borne by the government. Law Number 30 of 2014 on Government Administration (Law No. 30 of 2014) is intended by legislators to provide legal protection to citizens or government officials that make a decision or carry out an action. Protection from arbitrary decisions is provided under Article 70 paragraph (1), which governs the validity of a decision and/ or action when made or taken by a government agency and/or officer having no authority to do so, in a manner that exceeds their authority, or in an arbitrary fashion.

The advent of Law No. 30 of 2014 has raised its own problems in the governance of legal entities that can be held accountable for loss suffered by the State. This is due to the fact that such law states that other than government officials, government agencies can also be determined as being responsible for returning state losses under certain circumstances. Meanwhile, the concept of state losses or regional government losses always positions the State as the aggrieved party, not as the party that is accountable for the occurrence of the loss.

The law-making has the purpose of ensuring that the party suffering the loss receives payment or compensation commensurate to the value that it is entitled to (Markel, 2009). Further, when a decision and/or action is invalid, it can be rescinded on the basis of the implementation of incorrect procedure or any substantive error. Subsequently, any 
loss arising from the rescinded decision and/ or action will become the responsibility of the government agency and/or official in question.

Law Number 30 of 2014 is also meant to address the weakness found in the Law on State Administrative Judiciary, as now any factual action by the Government that in some cases can cause adverse effect on the public can serve as cause for litigation in the State Administrative Courts (Pengadilan Tata Usaha Negara or PTUN). By this regulation, the Government can no longer avoid the state administrative courts by issuing decisions only in written form (Siahaan, 2009). This provision expands the state administrative courts' authority to examine not only written administrative decisions, but also governmental actions (bestuurhandelingen), which not only comprise of formal written measure but also include "factual acts" (feitlijke handelingen). State administrative courts under this law can also examine governmental administrative actions as set forth in Article 1 paragraph 8 of Law Number 30 of 2014, which were originally examined by the general courts in cases involving alleged unlawful acts committed by officials (onrechtmatige overheidsdaad) pursuant to the general provisions governing unlawful acts contained in Article 1365 of the Indonesian Civil Code (KUH Perdata) (Wahyunadi, 2016).

Article 20 paragraph (5) of Law Number 30 of 2014 lends protection to government officials by placing the responsibility of reinstating state losses on the relevant government agency. This protection of government officials is intended to remove the obligation to compensate for losses suffered by the state resulting other than from the misuse of power by the government official in question. Under this clause, if a decision and/or action involves a loss suffered by the government, but the government in question did not commit any abuse of power, then such loss become the responsibility of the state. Conversely, if negligence is found to have been committed and there is evidence of misuse of power, then such loss becomes the personal liability of the government official (Yulius, 2016).

From the annotation document to Law Number 30 of 2014 issued by the Center for Study of Governance and Administrative Reform (UI-CSGAR) in collaboration with the Ministry of Utilization of State Aparatus and Bureaucratic Reform (UI-CSGAR, 2017), it is known that far before the submission of the Draft Law on Government Administration by the Government to the Indonesian House of Representatives (DPR), the proposed clause governing this authority has received much input, comments and criticisms. One of such criticisms was raised during a Limited Cabinet Session in 2007, asserting that in a situation where the decision of a public official is deemed to be erroneous by the ruling of a State Administrative court and it is also ruled that a fine or compensation must be paid, then it should be made clear whether it is the public official or the government agency/institution that will bear the fine or compensation. Additionally, it was suggested that the related sanction should be elaborated, at which level administrative sanctions should also be able to be applied.

It is also known that during a Working Committee Meeting between the DPR and the Government on 1 September 2014, an agreement was reached that discussion on the Inventory of Issues (Daftar Inventaris Masalah or DIM) with respect to Article 90 to Article 186 of the Draft Law on Government Administration (therefore including Article 17 up to Article 21) is left to the Drafting Team. The work of the Drafting Team was discussed during a meeting 
between them and the Synchronization Team on 3 September 2014. The drafting session agreed that there needs to be a textual change to the provision of Article 20, namely the addition of a new paragraph (6) and paragraph (7). Paragraph (6) determines that returning of state losses as referred to in paragraph (5) is to be borne by the Government agency in question in the event the administrative error is not caused by misuse of authority. Meanwhile, paragraph (7) determines that the responsibility of reinstating state losses as referred to in paragraph (5) is to be borne by the public official if misuse of authority is found to have caused such administrative error.

To examine and determine which entity should be responsible for losses suffered due to a decision and/or action a certain process will be applied. Law Number 30 of 2014 states that the authority to examine whether such misuse of authority was committed lies with the Internal Government Auditors (Aparat Pengawasan Intern Pemerintah APIP), who through their monitoring activities can arrive at any of the following conclusions:

1. No error has been committed;

2. An administrative error has occurred; and

3. An administrative error has occurred which caused state financial loss.

With regard to the conclusion made by the Internal Government Auditor, state loss arising from an administrative error is governed by Article 20 paragraph (5) and paragraph (6). As such, the Law allows the responsibility for state loss to be placed on a government agency and free the particular government official from the obligation to reinstate the loss suffered. This is possible provided that no misuse of authority is presented despite the decision and/or action was being made or carried out by the official in question. If in practice there occur a condition where the government agency is required to pay compensation for losses suffered by the state, another problem may arise. The problem relates to the question as to whether payment of such compensation should be made through the National Budget (Anggaran Pendapatan dan Belanja Negara or APBN) or through the Regional Budget (Anggaran Pendapatan dan Belanja Daerah or APBD), as well as to under what budget item and through what activity program can such repayment of state losses can be realized.

The purpose of this study is to determine the alignment of the legal norms that govern which legal entities can be held accountable for state losses as provided under Law Number 30 of 2014 with the theory of state administrative law and rules of state finance that apply in Indonesia. The result of this study is expected to benefit government agencies, the BPK in particular, in exercising their authority. Outcome of this study is also hoped to inform the Government and the House of Representatives as legislators in refining Law Number 30 of 2014 in the future.

\section{RESEARCH METHOD}

The present study applies legal norms as enshrined in the relevant regulations, including principles of the law that serve as references, particularly in state finances. The research typology used is prescriptive, namely a study aimed to generate recommendations as to what measures need to be take to address particular issues (Mamudji, 2005). This particular study has the purpose of formulating recommendation to enhance applicable norms governing subjects that are determined to be accountable for state losses under Law Number 30 of 2014. This study was initiated do to the fact that prior studies have not discussed persons accountable in such situations. 


Data source utilized in this study is limited to
secondary data that cover primary,

Table 1. Legal Subjects Accountable for State Losses under State Finance Laws

\begin{tabular}{ccc}
\hline Law & Article Text & $\begin{array}{c}\text { Legal Subject Accountable } \\
\text { for State Losses }\end{array}$ \\
\hline
\end{tabular}

Law Number 17 Article 35 paragraphs (1) and (2)

of 2003 on State (1) Any state official and civil servant other than treasurers who commits Finances

an offense or omits to perform their obligations, whether directly or indirectly, causing state financial loss to occur shall be required to provide compensation for such loss.

(2) Any person assigned with the task of receiving, maintaining, paying, and/or delivering money or commercial papers or state-owned goods shall be a treasurer required to submit an accountability report to the Supreme Audit Agency.
1. State official;

2. Civil servants other than treasures; and

3. Treasurers
Law Number 1 of Article 59 paragraph (2):

2004 on State (2) A treasurer, civil servant other than treasurer, or other officials who Treasury due to their action has violated the law or omits to perform the obligations assigned to them thus directly causing financial loss to be suffered by the state, shall compensate for such loss.

Elucidation to Article 59 paragraph (2):

The term other officials include state officials and officials undertaking governmental functions who do not bear the status of state official, not including treasurers and civil servants other than treasurers.
1. Treasurer;

2. Civil servants other than treasurers;

3. Other officials including state officials and officials undertaking governmental functions who do not bear the status of state official, not including treasurers and civil servants other than treasurers.

1. Treasurer

Law Number 15 Article 10 paragraph (1):

2. Manager Owned

of a State-

Audit Board the state due to an unlawful act committed willfully or in negligence by (BPK) the treasurer, manager of a state-owned enterprise/ regional government -owned enterprise, and institutions or other agencies in charge of managing state finances.

Article 10 paragraph (3)

(3) To ensure the payment of compensation, the BPK has the authority to monitor: a. settlement of the compensation to the state/regional government as determined by the Government on the civil servant other than treasurers and other officials; $b$. performance of the obligation to provide compensation for loss suffered by the state/regional government on the treasurer, manager of a State-Owned Enterprise/ Regional Government-Owned Enterprise, and institution or other agencies managing state finances as determined by the BPK; and c. performance of the obligation to provide compensation for loss suffered by the state/ regional government as determined by a court ruling having permanent legal force.

Elucidation to Article 10 paragraph (1)

The term "manager" include the employees of state/regional government -owned enterprise or other institutions or agencies.

Elucidation to Article 10 paragraph (3)

Sub-paragraph a: The term "other officials" refers to state officials and officials undertaking governmental functions that do not bear the status of state official.

Sub- paragraph b: Sufficiently clear.

Sub-paragraph c: Settlement of compensation for state losses due to the unlawful act of a third party is effected through a judicial process.
Regional Government-

Owned Enterprise or

other institutions/

agencies managing state

finances, including

employees of state/ regional governmentowned enterprise or other institutions or agencies;

3. Civil servants other than treasurers and other officials (state officials and officials undertaking governmental functions who do not bear the status of state official); and

4. Third parties.

Source: Secondary Data (Law Number 17 of 2003, Law Number 1 of 2004 and Law Number 15 of 2006), processed by author. 
conducted by exploring the researched objects, namely Law Number 30 of 2014, followed by analysis of data based upon the concepts of state administrative law as well as synchronization with other laws applicable in the country. Result of the analysis is used as material to establish a legal construct on the legal subjects governed under Law Number 30 of 2014 that can be held accountable for losses suffered by the state.

\section{RESULT AND DISCUSSION}

\section{Legal Subjects That Responsible for Returning of State Loss Based on Law Number 30 of 2014}

According to Article 1 paragraph 16 of Law Number 14 of 2006, upon the incurrence of state loss, the state is the legal subject suffering the loss (Halim \& Bawono, 2011). Based on the terminology "state loss", the state is the party suffering the loss due to the unlawful action committed by another party. As such the state is the party entitled to demand compensation from the party causing such state loss.

Prior to Law Number 30 of 2014 being passed, various legal instruments governing state finances have identified legal subjects that can be held accountable for state losses. These laws include Law Number 17 of 2003 on State Finances, Law Number 1 of 2004 on State Treasury and Law Number 15 of 2006 on the Audit Board. Table 1 presents legal subjects that can be potentially be held accountable for state losses under various Indonesian laws.

According to the above regulatory provisions, it can be concluded that persons that are able to be held accountable for state losses are as follows:

1. civil servant treasurer;

2. civil servant other than a treasurer;
3. other officials, namely state officials and officials undertaking government functions who do not bear the status of state official; and

4. third parties.

\section{Legal Analysis of Legal Subjects Who Can Be Held Accountable for State Losses}

Following the passage of Law Number 30 of 2014, there was an expansion of the categories of legal subjects who can be held accountable for state losses, namely government agencies. Etymologically speaking, the term "government agency" contains two elements, namely "government" and "agency". Nugraha (2005) defines agency in a state administrative law context, which is a group of people forming a unit having the power to achieve a common purpose. Based on such definition the primary characteristic of an agency is collectivism of a group of people conferred with authority as part of a sovereignty.

The definition of governance needs to be differentiated from government. Government is a state entity while governance is an activity carried out by the government (Lembaga Pemilihan Umum, 1978). Government is the entity wielding the power in a state, while governance is the activity or any action undertaken by the government in the exercise of such power. Atmosudirjo in Danesjvara (2005) defines government agency as a public administrative organization. A public administrative organization itself is given the definition as the entire institutional of public administration comprising of ministries, and/or departments, directorates and bureaus, districts, autonomous regions and so forth (Danesjvara, 2005). This definition is closer to the definition of governance in its narrowest sense, which is restricted to executive powers. 
Based on the definitions presented by the legal experts, it can be concluded that the definition of government agency is a body or organ of the state as the legal unit with the power and mandated with enforcement authority in carrying its governmental duties (bestuur functie) to achieve the objectives of the State.

A major misstep in the drafting of Article 20 paragraph (5) and paragraph (6) of Law Number 30 of 2014 is to confuse the concept of state loss with the concept of public loss caused by the unlawful act by the entity in power, when the two concepts have a very fundamental difference.

When public loss occurs due to an unlawful act by those in power, the adversely affected party is the public. Meanwhile, in cases involving state loss, the aggrieved party is the State represented by the relevant government agency. Therefore it does not stand to reason if it is stipulated that a government agency is liable for compensation for a loss that itself is suffering.

Upon deeper analysis of Article 20 of Law Number 30 of 2014, it can be seen that there is ambiguity in the formulation of such article. This can be more clearly seen when we examine the wording of paragraph (1) of the article, which states that supervision by the government internal auditors (APIP) is performed to determine whether there is a misuse of power by the relevant governmental administrative agency and/or official. Further in Article 20 paragraph (2) it is stated that the result of the supervision is limited to three conditions:

1. no error/misconduct has occurred;

2. administrative error has occurred; and

3. administrative error has occurred which causes the State to suffer a loss.

This causes ambiguity as the result of such supervision would not determine whether there has occurred a misuse of power committed by a government administrative body and/or official. The laws even give rise to the further question as to whether or not the administrative error is tantamount to a misuse of power. If the affirmative answer is assumed, then possible outcomes of a supervision conducted by the internal government auditor can be taken as follows:

1. no misuse of authority has occurred;

2. a misuse of authority has occurred; and

3. a misuse of authority has occurred which causes the State to suffer a loss.

Meanwhile, as previously explained, according to Article 17 paragraph (2) of Law Number 30 of 2014, a misuse of authority may be:

1. an action exceeding established authority; 2. an action which crosses multiple authority; and

3. arbitrary action.

The above legal provision clearly states that misuse of authority would not only result in an administrative wrong but can also have larger impact, even as far as corruption in the public sector that affects the state's financial performance (Petrou, 2015). Such a situation can be illustrated in the following example: a Department Head at the Agriculture Office in District A issues an assignment letter to a number of his staff to undertake official travel, even though as per regulation the authority to issue assignment letters only lies with the Head of Office. This means that the Section Head has overstepped his authority by signing the letter. In this case such error can be deemed as being merely an administrative error and can be rectified.

However, if the case involves the Head of Agricultural Office of District A giving orders to the Section Head to falsify proof of an non -existent official travel so as to allow reimbursement for the cost of the fictitious travel to be enjoyed privately, then such 
misuse of authority cannot be deemed as being an administrative error, and even can be an indication of corrupt practice. This demonstrates that the provisions of Article 20 paragraphs (1) and (2) of Law Number 30 of 2014 appears to strongly protect public officials by treating all manners of misuse of authority merely as an administrative error.

From a state administration law and state finances perspectives, setting a government agency as the legal subject liable for reinstating state loss is inappropriate. Such a provision is contradictive to the definition of state loss as given in Article 1 sub-article 22 of Law Number 1 of 2004, which establishes state loss as a factual diminishing money, commercial paper, and goods of a definite amount as a result of an unlawful act, whether committed willfully or in negligence. Under this definition, the diminishing money, commercial papers and goods refers to the assets of the State.

The state's position as a legal subject suffering the loss is explicitly stated in the definition of compensation under Article 1 sub-article 16 of Law Number 15 of 2006. Based on such laws, it can surmised that in the event of a loss suffered by the State, the State would be in the place of the aggrieved legal subject (Halim \& Bawono, 2011) and therefore such loss must be returned to the State. State as used in the term "state loss" is the entity suffering the adverse effect of the unlawful act committed by another legal person. As such, the State is the party most entitled to claim compensation against such other person who is responsible for causing the state loss to occur.

The argument that the provisions of Article 20 paragraph (5) of Law Number 30 of 2014 is incorrect is based on the definition of government agency itself. The definition of government agency in that law can be found in its Article 1 sub-article 3, namely a unit that undertakes governmental functions, whether within the government or other state institution. As such, a Government Agency can be seen as the representation or manifestation of the State and, therefore, from a state administration law perspective, it can require accountability for state losses from legal subjects that are specified in the state finance laws.

In light of the above, a government agency cannot be made as the legal subject that is responsible for a state loss. Therefore, Article 20 paragraph (5) of Law Number 30 of 2014 which determines that compensation for state losses that are not the result of misuse of authority can be made as the liability of the government agency, is incorrect and creates a contradiction with clauses on state losses contained in state finance laws. Ambiguity between State Loss and Public Loss Arising from Unlawful Act Committed by Government Authorities Under Law Number 30 of 2014.

The provisions of Article 20 paragraph (5) of Law Number 30 of 2014 has created an ambiguity between the concepts of state loss and public loss arising from unlawful acts committed by government authorities. According the concept of state loss, the party subjected to the adverse effect is the state, which in this case is represented by the relevant Government Agency. Meanwhile, according to the understanding of public loss that is caused by an unlawful act committed by the government authorities, the party suffering such loss is the public. However, the term "state loss" as used in Article 20 paragraph (5) has confused the concept of state loss with public loss caused by an unlawful act committed by the government, where in the latter situation compensation can indeed be borne by the State as represented by the relevant Government Agency. 
The concept of compensation for public loss that can be imposed on a Government Agency can be found in Government Regulation (PP) Number 43 of 1991 on Compensation and Methods of Implementation at the State Administrative Courts, being the operational regulation of Law on State Administrative Judiciary. The provisions of Article 1 sub-article 1 of the same regulation defines compensation as follows:

"Compensation is the payment of a certain amount of money, either to an individual person or private legal entity, at the liability of the relevant State Administrative Body pursuant to judgment rendered by a State Administrative Court, arising from a actual loss suffered by the claimant."

According to the above definition, it can be clearly understood that the party suffering the loss is the public, which can consist of individual persons or legal entities. Payment of money to compensate for such loss is imposed on the State Administrative Body or, as the term is used in Law Number 30 of 2014, the Government Agency.

With regard to the imposition of liability for the loss on the relevant Government Agency, further provisions are contained in Article 2 of the aforesaid Government Regulation Number 43 of 1991:

(1) Compensation that becomes the liability of a Central State Administrative Body shall be borne under the National Budget (APBN)

(2) Compensation that becomes the liability of a Regional (Sub-National) Administrative Body shall be borne under the Regional Budget (APBD)

(3) Compensation that becomes the liability of a State Administrative Body other than those specified in paragraph (1) and (2) shall be borne by the budget managed by such body.

Pursuant to the above regulations, it is clear that payment of compensation for public loss resulting from unlawful act committed by government will be imposed on the relevant Government Agency, and such payment will be made by the State and/or regional government to the aggrieved public from the National Budget (APBN) and/or Regional Budget (APBD).

Compensation disbursed out of the National Budget as mentioned above is governed in more detail under Decree of the Minister of Finance Number 1129/KMK.01/1991 on Procedure for Payment of Compensation as Implementation of the Judgment of a State Administrative Court. The relevant clause that needs to be noted in the said Decree is contained in Article 3:

(1) Based on a Decree of Authorization (Surat Keputusan Otorisasi or SKO) as specified in Article 2 paragraph (4), the entitled party shall submit a request for payment of compensation to the State Treasury Office (Kantor Perbendaharaan dan Kas Negara or KPKN) through the local State Administrative Body, by attaching a) the Decree of Authorization, b) original and photocopy of excerpt of the State Administrative Court judgment.

(2) The State administrative Body as referred to in paragraph (1) shall submit a Direct Payment Request (Surat Perintah Pembayaran Langsung or SPPLS) to the paying KPKN.

Additionally, Article 4 paragraph (1) of the above Ministerial Regulation should be noted:

"The State Treasury Office shall issue a Direct Payment Instruction (Surat Perintah Membayar Langsung or SPMLS) to the entitled party."

Based on such regulation, payment of compensation out of the State treasury is made by the government agency representing the government to the entitled 
member of the public, namely the person determined by the State Administrative Court as being the party suffering the loss. As such, if the procedure was to be applied to a case where there occurred a state loss, it would become illogical if a government agency is determined to be responsible for the loss, and subsequently file a request for compensation to only be paid using money sourced the State's funds. This shows that a governmental body cannot be made accountable for state loss, as they are representatives of the State and cannot be liable for a loss that they suffer themselves. The above explanation shows that the provisions of Article 20 paragraph (5) of Law Number 30 of 2014 contains ambiguity as the concepts of state loss and public loss arising from unlawful acts committed by the government.

\section{Analysis of Accountability of Govern- ment Officials in the Returning of State Loss Based on The Law Number 30 of 2014}

The stipulation of Article 20 paragraph (5) of Law Number 30 of 2014 is intended to extend legal protection to government officials who are acting in good faith (te goeder trouw) in discharging their duties. This clause provides such protection by diverting liability to return the loss to the government body if it is found that the state loss was not caused through the misuse of authority by the government official in question. Further, Article 20 paragraph (6) states that the responsibility for reinstating state loss lies with a government official only if such loss was caused by a misuse of authority on the part of the official in question. However, the wordings used in both paragraph (5) and (6) of the article create a legal issue, as they do not align with regulations on state losses as provided in existing state finance laws. Synchronization of laws is very important as regulatory provisions on state finances are all derived from the Indonesia's 1945 Constitution, which confers mandate to legislators to formulate content of the laws that enshrine this aspect (Saidi, 2013).

If Article 20 paragraphs (5) and (6) are interpreted using a historical review (theory of original intent), the government intends for states losses that are not caused by a misuse of authority to become the liability of the institution (office), as set forth in the Annotation of the Law on Government Administration (UI-CSGAR, 2017). However, the idea and intention of the government to save government officials from being liable for state loss that arises other than from willfulness contradicts the ideals of creating a government that is professional and accountable. This can potentially prevent government officials from conducting analysis of the risk of adverse effect on the public that may be brought about by a decision he or she is about to make, as they would not be held liable for compensation. The norms enshrined in Law Number 30 of 2014 must be in line and must contradict regulations on state finances in order to be applicable. Law Number 17 of 2003 and Law Number 1 of 2004 constitute the underlying legal instrument of state financial management (Tim Pengkajian Hukum BPHN, 2011).

The lack of synchronicity between Law Number 30 of 2014 and the aforesaid laws of finance is apparent from two aspects. The first is the provision of Article 20 paragraph (5). If the intention of the article is to provide legal protection to the related government official, there should not be a need to divert the liability of providing compensation to the government institution, as it only makes for a useless and ineffective requirement. The article should only specify that there are certain losses suffered by the state that occur under particular circumstances, or which due to their nature, that cannot serve as grounds for claim of compensation. The 
clause providing reassignment of liability to the government institution is not consistent with the definition of state loss, according to which the state, represented by the government institution, is placed as the party adversely affected by the loss. Additionally, if the burden of reinstating state loss is placed upon the budget of the government institution whose resources are derived from the State's treasury, such liability would have the effect of reducing or diminishing the performance of the institution. This is due to the fact that there never have been any allocation of budget to compensate for State's financial loss that might occur.

Secondly, Article 20 paragraph (6) exhibits some ambiguity in its wording. The article appears to state that the obligation to reinstate state loss can be imposed only if such condition occurs as a result of misuse of authority, while in fact errors caused by negligence or omission must also be accounted for. This is affirmed in the provisions of Article 59 paragraph (1) and paragraph (2) of Law Number 1 of 2004:

(1) Any loss suffered by the state/regional government caused by an unlawful act or omission of a person must be settled forthwith in accordance with the law.

(2) Treasurers, civil servants other than treasurers, or other officials by reason of their commission of an unlawful act or omission of the obligation that has been placed in their charge, have directly caused financial loss to be incurred by the state, shall be obligated to compensate such loss.

State loss that occurs due to negligence is the key issue, as negligence is clearly not a form of misuse of authority. Nevertheless, a government official who has been found in negligence, in accordance with Article 59 paragraph (1), should still be imposed with the obligation to compensate for the resultant state loss. As such, it can be said that not all actions that do not constitute a misuse of authority should preclude government officials from being obligated to compensate state loss.

In order to avoid a legal loophole, the stipulations of Article 20 paragraph (5) of Law Number 30 of 2014 should be further elaborated in a regulation that specifies additional conditions that must be satisfied in order for a government official to be exempted from the obligation to compensate state loss. In addition to the condition that the loss did not occur as a result of a misuse of authority, it should also be required that the loss was not due to a negligence on the part of the official. Introducing a legal provision to extend legal protection and limitation of liability to public officials is a rational measure. However, if such intention is realized by shifting the liability of compensating for state loss to the government agency, it creates an irrational regulation. Likewise, if the limitation of responsibility to return state loss that should be the liability of the government official is determined merely based on the presence or absence of misuse of authority.

There are at least three conditions whereby a government official can be given a limitation as regards to, or even be fully released from, his obligation to compensate for the state loss that occurred. This is possible in the event the state loss was incurred under specific circumstances, or when the nature of such loss does not allow the official to be held accountable. Such conditions elaborated as follows:

1. Limitation of liability of government officials from an administrative law and criminal law aspect with respect to state losses caused by an unlawful act involving negligence. Where the decision and/or action was made or taken strictly due to a misjudgment based on incorrect key consideration (zelfstandingheid der zaak), the position of a person and the rights of a 
person (dwaling in een subjectief recht), or a misinterpretation of a regulation (dwaling in het objectief recht), and misconstruction of one's own authority (dwaling in eigen bevoeheid) do not constitute state loss in the context of criminal law, specifically the crime of corruption. Such condition constitute a case of maladministration that can still be subject to claim of compensation.

2. Legal protection for government officials with regard to state loss resulting from a force majeure event. Among the examples of this type of events are acts of God, such as fire, natural calamity, power outage, war, invasion, rebellion, revolution, embargo, labor dispute, or sanction imposed on a government (Bishoff \& Miller, 2009), which often lead to the state suffering a loss, as when state-owned assets such as buildings or official vehicles become lost or damaged.

3. Legal protection for government officials with respect to state loss occurring due to fiscal risks, namely the risk of a future event causing fiscal strain on the National Budget (APBN) or excessive burden on available funding.

Taking in account the above conditions, there needs to be a clear limitation of liability for government officials who, through their action, have caused a state loss to occur. There should be a clear distinction between responsibilities applicable to officials who caused a state loss in a willful manner and with corrupt intent taking advantage of the opportunity arising during the performance of their duties or for personal motivations (Johnson, Rachel, \& Kidd, 2014) and those applicable to officials who have caused state loss purely as a result of their negligence. According to Sianturi (1982), criminal accountability is a form of assessment to test whether a suspect or defendant can be held accountable for a crime that took place.
A decision and/or action by a government official can be qualified as misuse of authority within the context of corruption only if such decision and/or action contains elements of fraud, conflict of interest, illegality, or gross negligence. If these parameters cannot be proven, there are two possible conclusions, namely that such decision and/or action is a pure negligence caused by lack of knowledge, inexperience or unprofessionalism (malpractice) or a failure to perform an obligation, or it can be an unlawful act as defined in Article 1365 of the Indonesian Civil Code. Regulation governing the obligation to pay compensation for loss arising from an unlawful act is an issue that is important to be incorporated in the laws, as fraud committed by people of authority at the national as well as subnational level has caused significant losses (Puspasari, 2016).

State loss for which accountability can be expected under state administrative laws and state loss that must be answered for in a criminal proceeding, particularly involving corruption, must be differentiated. Simatupang (2011) views that a state loss can be categorized as arising from an unlawful act under the penal code, particularly anticorruption laws, only if the loss contains the following statutory elements:

a. coercion (dwang) or bribery (omkoperij), where the state loss was incurred due to coercion being applied by a party, whether directly or indirectly, or due to political pressure, followed by the giving of a promise or an attempt to furnish an object with the intention of influencing an action that result in the diminishment of money, commercial papers, or asset of the State; and

b. a fraudulent act committed through deceitful methods (kuntsgrepen), where the state loss is caused by the use of money, commercial papers, and assets of 
the state made to falsely appear to be in compliance of the applicable regulations, or when the actual facts or events are inconsistent with the reason for which such money, commercial paper and asset of the state were utilized.

State loss that contains any of the above statutory qualification is declared as null and void by law (nietig van rechtwege) and thus can be categorized as an unlawful act under criminal laws, particularly corruption. However, not all unlawful acts are crimes. This is in line with the opinion expressed by Atmasasmita, which states that a maladministration committed by law enforcement or government authority does not automatically constitute corruption even if they have resulted in state loss (Yulius, 2016). Where the state administration official or government official involved acted in good faith in performing their state administrative or governmental tasks in their appropriate capacities, then ideally they cannot be held accountable as perpetrator of corruption (Nodi, 2013). An example of the difference between state loss caused by an unlawful act as a result of negligence and state loss occurring in consequence of a willful act is when a payout treasurer makes an error while preparing the payroll, causing the nominal amount being paid to an employee to become higher than what is entitled. Such excess in payment went unnoticed by the employee who spent the amount in a normal fashion. At some later date the problem was discovered during an audit by the internal auditor (APIP). If the issue is limited to those facts, then the state loss is indeed the result of negligence and only needs to be accounted for administratively by recovering the excess amount and returning it to the state/ regional government's funds. However, the nature of the accountability would be different if the audit conducted by the internal auditor finds that the payout treasurer deliberately overpaid the salary and subsequently require the employee to return the overpaid amount citing the reason that there has been a mistake made in the calculation of the salaries. The returned mount is then spent by the treasurer for his/ her personal needs. If the latter is what transpires, in addition to the loss having to be accounted for administratively by returning it to the state treasury, the action must also be accounted for in a criminal proceeding as corruption.

In a case where state loss occurred as a result of an unlawful act arising from negligence alone should be limited as to the accountability of the official in question in accordance with the applicable procedures under state administrative laws, namely whether through compensation for the loss and/or imposition of administrative sanctions in accordance with the applicable laws. Conversely, if the state loss is proven to have occurred due to an unlawful act with intent, in order to achieve a malicious purpose (mens rea), contains an element of fraud, etc., then the official involved shall not only have to provide compensation for the state loss but must be criminally liable. As such, pursuant to Article 20 of Law Number 30 of 2014, which states that government officials can only be imposed with the obligation of reinstating state loss if such loss contains misuse of authority, is erroneous.

\section{CONCLUSION}

The legal provisions governing the position of government institutions as party to be held accountable for state loss as laid out in Article 20 paragraph (5) of Law Number 30 of 2014 is not correctly formulated, as the definition of state loss is loss suffered by the state resulting from an unlawful act committed by another party. Meanwhile, a government institution can be defined as the 
manifestation or representative of the State, thus it would not correct if the state is imposed with the responsibility of providing compensation for a loss that itself had incurred.

The clause that states government officials can only be imposed with the obligation to make compensation for state loss if such loss is brought about by a misuse of authority and in the contrary if misuse of authority was not committed, then the responsibility must be shifted to the government agency in question is erroneous. The existence of this clause makes it appear that government officials can only be held liable for state loss if he or she commits a misuse of authority, whereas loss suffered by a sub-national government due to an unlawful act committed through negligence also cannot be categorized as a misuse of authority while the government involved would still be held liable to reinstate the loss.

Amendments that can be introduced would be to revise or replace the clause as it is presently set forth in Article 20 paragraph (5) of Law Number 30 of 2014, which currently determines that a government institution can be held liable for state loss to become as follows:

"Returning of a state loss as referred to in paragraph (4) shall be for the account of the government official in question regardless whether an administrative error as referred to in paragraph (2) sub-paragraph $c$ occurred without any element of misuse of authority."

Additionally, a revision needs to be effected on Article 20 paragraph (6) of the same law, which should stipulate that state loss occurring as a result of an unlawful act committed in negligence by a government official shall still give rise to the obligation to provide compensation on the part of the government in question, while the wording of the clause may be as follows: "Returning of state loss as referred to in paragraph (4) shall be the liability of the government official in question if the administrative error as referred to in paragraph (2) subparagraph $c$ occurs due to a misuse of authority or negligence."

\section{REFERENCES}

Agustina, R., Nieuwenhuis, H., Hijma, J., \& Suharnoko. (2012). Hukum perikatan. Denpasar: Pustaka Larasan.

Bentham, J. (2010). Teori perundangundangan, prinsip-prinsip, hukum perdata dan hukum pidana (Nurhadi, Translator). Bandung: Nuansa dan Nusa Media.

Bishoff, T. S., \& Miller, J. R. (2009). Force majeure and commercial impractiability: Issues to consider before the next hurricane or natural disaster hits. The Michigan Business Law Journal, 29(1), 16-22.

Decree of the Minister of Finance Number 1129/KMK.01/1991 about Procedures for Payment of Compensation for the Implementation of Decisions of the State Administrative Court. (Keputusan Menteri Keuangan Nomor 1129/KMK.01/1991 tentang Tata Cara Pembayaran Ganti Rugi Pelaksanaan Keputusan Pengadilan Tata Usaha Negara). Retrieved from https://jdih.kemenkeu.go.id/ fullText/1991/1129 KMK.01 1991Ke p.HTM.

Danesjuara, A. (2005). Hukum dan administrasi publik. Suatu pengantar kajian hukum dalam konstruksi manajemen negara. 
Jakarta: Badan Penerbit Fakultas Hukum Universitas Indonesia.

Government Regulation Number 43 Year 1991 on Compensation and Implementation Procedures in the State Administrative Court (Peraturan Pemerintah Nomor 43 Tahun 1991 tentang Ganti Rugi dan Tata Cara Pelaksanaanya pada Peradilan Tata Usaha Negara (LN Tahun 1991 Nomor 52, TLN Nomor 3448)).

Halim, A., \& Bawono, I. R. (2011). Pengelolaan keuangan negaradaerah: Hukum, kerugian negara, dan badan pemeriksa keuanganedisi pertama: kepastian hukum penyelenggara keuangan dalam pengelolaan keuangan negaradaerah. Yogyakarta: UPP STIM YKPN.

Herstein, J. O. (2015). How tort law empowers. The University of Toronto Law Journal, 65(1), 99-132.

Johnson, G. F., Rachel, H., \& Kidd, B. (2014). Three essentials internal controls for public sector entities. Journal of Government Financial Management, 47-51.

Lary, A. M., \& Taylor, D. W. (2012). Governance characteristics and role effectiveness of audit committees. Managerial Auditing Journal, 27(4), 336-354.

Law of the Republic of Indonesia Number 17 of 2003 on Financial State (UndangUndang Nomor 17 Tahun 2003 tentang Keuangan Negara). Retrieved from http://www.bpk. go.id/assets/files/storage/2013/12/ file_storage_1386152419.pdf .
Law of the Republic of Indonesia Number 1 of 2004 on State Treasury (UndangUndang Nomor 1 Tahun 2004 tentang Perbendaharaan Negara). Retrieved from http:// www.bpk.go.id/assets/files/storage/ 2013/12/ file_storage_1386161111.pdf.

Law of the Republic of Indonesia Number 15 of 2006 on The Audit Board (Undang -Undang Nomor 15 Tahun 2006 tentang Badan Pemeriksa Keuangan). Retrieved from http:// bandung.bpk.go.id/files/2009/o3/ UU-15-Tahun-2006.pdf.

Law of the Republic of Indonesia Number 30 of 2014 on Government Administration (Undang-Undang Nomor 30 Tahun 2014 tentang Administrasi Pemerintahan). Retrieved from https://jdih. kemenkeu.go.id/fullText/2014/ 30TAHUN2014UU.HTM.

Lembaga Pemilihan Umum. (1978). Penyelenggaraan Pemerintahan Berdasarkan Undang-Undang Dasar 1945, Jakarta: Sekretariat Jenderal Departemen Dalam Negeri.

Makawimbang, H. F. (2014) Kerugian Keuangan Negara Dalam Tindak Pidana Korupsi, Suatu Pendekatan Hukum Progresif. Yogyakarta: Thefa Media.

Mamudji, S. (2005). Metode penelitian dan penulisan hukum. Jakarta: Badan Penerbit Fakultas Hukum Universitas Indonesia.

Markel, D. (2009). Retributive damages: A theory of punitive damages as intermediate sanction. Cormell Law Review, 94(2), 239-340.

Nota Keuangan Beserta Rancangan 
Anggaran Pendapatan dan Belanja Negara Tahun Anggaran 2018.

Nugraha, S. (2005). Hukum administrasi negara. Jakarta: Badan Penerbit Fakultas Hukum Universitas Indonesia.

Petrou, A. P. (2015). Arbitrariness of corruption and foreign affiliate performance: A resource dependence perspective. Journal of World Business, 5o(4), 826-837.

Puspasari, N. (2016). Fraud theory evolution and its relevance to fraud prevention in the village government in Indonesia. Asia Pacific Fraud Journal, 2(1), 177-188.

Saidi, M. D. (2013). Hukum keuangan negara. Jakarta: PT Raja Grafindo Perkasa.

Siahaan, L. O. (2009). Teori dan wajah hukum peradilan tata usaha negara setelah amandemen 2004. Jakarta: Perum Percetakan Negara.

Simatupang, D. P. (2011). Paradoks rasionalitas perluasan lingkup keuangan negara dan implikasinya terhadap kinerja pemerintah. Jakarta: FHUI Press.

Soepardi, E. M. (2006). Memahami akuntansi keuangan. Jakarta: Rajawali Pers.

Tim Pengkajian Hukum BPHN. (2011). Sistem pengelolaan keuangan negara. Jakarta: Badan Pembinaan Hukum Nasional, Kementerian Hukum dan HAM.

Tjandra, W. R. (2014). Hukum keuangan negara. Jakarta: PT Grasindo.
Tuanakotta, T. M. (2007). Percikan permenungan tentang kerugian negara. Paper presented at Workshop Pembuktian Unsur Kerugian Negara dan Perhitungannya Dalam Tindak Pidana Korupsi, Jakarta, Indonesia.

UI-CSGAR. (2017). Anotasi Undang-Undang Nomor 30 Tahun 2014. Jakarta: UICSGAR.

Wahyunadi, Y. M. (2016). Kompetensi absolut pengadilan tata usaha negara dalam konteks UndangUndang Nomor 30 Tahun 2014 tentang administrasi pemerintahan. (Disertasi). Universitas Trisakti, Jakarta.

Yulius, H. (2016). Undang-Undang administrasi pemerintahan dalam upaya pemberantasan korupsi. Jakarta: Sinar Grafika. 


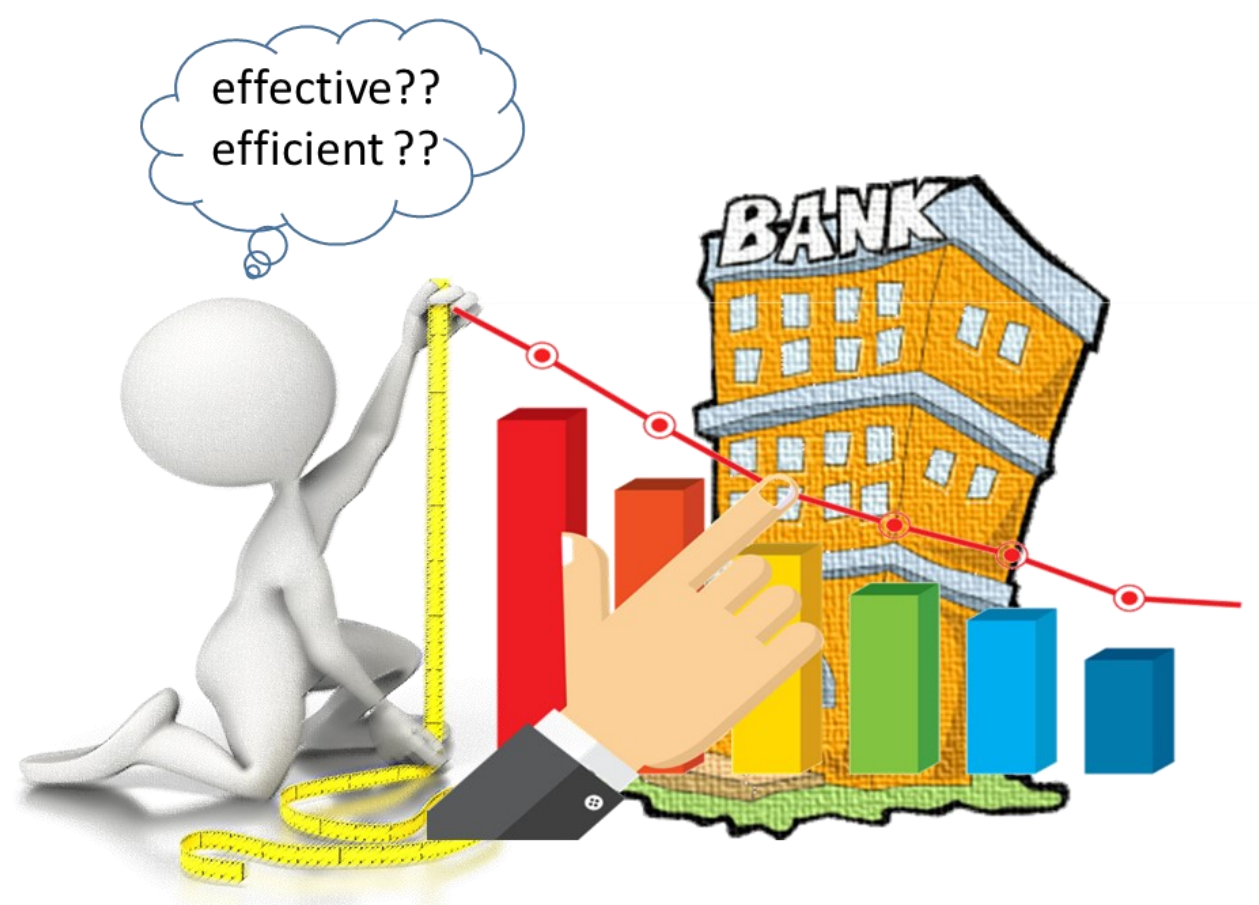

